PROCEEDINGS OF THE WORLD CONFERENCE ON OZONE THERAPY IN MEDICINE, DENTISTRY AND VETERINARY. ANCONA (ITALY). SEPTEMBER 22nd - 23rd - 24th, 2017

\title{
Ozone therapy in the treatment and cure of Ebola disease [abstract]
}

\author{
Robert Jay Rowen
}

Private Medical Practice. Santa Rosa, California, United States of America

\section{ABSTRACT}

\section{O OPEN ACCESS}

\section{Citation}

Rowen RJ. Ozone therapy in the treatment and cure of Ebola disease [abstract]. Proceedings of The World Conference on Ozone Therapy in Medicine, Dentistry and Veterinary. Ancona (Italy). September 22nd - 23rd - 24th , 2017. J Ozone Ther. 2019;3(4):53. doi: 10.7203/ jo3t.3.4.2019.15533

\section{Academic Editor \\ Jose Baeza-Noci, \\ School of Medicine, Valencia University, SPAIN}

\section{Editor}

World Federation of Ozone Therapy, Bolgna, ITALY

\section{Received}

June 17, 2019

\section{Accepted}

December 08, 2019

\section{Published}

December 30, 2019

Intellectual Property

Robert Jay Rowen.

This is an open access article distributed under the terms of the

Creative Commons Attribution License (CC BY 4.0), which permits

unrestricted use, distribution, and reproduction in any medium, provided the original author and source are credited.

\section{Author Information} docrowen@gmail.com
Background. Ebola Virus Disease (EVD) has ravaged three countries in West Africa. The mortality rate is extremely high, and it is perceived not only as threat to all of Africa but to the entire world. There is no known treatment to date other than administration of convalescent blood or experimental monoclonal antibodies, which both often fail. Ozone therapy (OT) has been in clinical use for decades and has been found to have physiological effects, which should directly inactivate the virus itself, as well as modulate its damaging effects. We present the scientific background and the possibility of ozone therapy as a cure or prevention for EVD in five consecutive patients.

Material and Methods. Ozone therapy administration by a combination of direct intravenous gas administration, rectal gas administration and ozonized water was administered to three patients with known acute EVD, one with apparent acute infection, and one case of extremely high risk. Treatment was carried out for up to ten days despite fast total remission of symptoms. Vitamin $\mathrm{C}$ and glutathione supporting supplements were administered.

Results. Four symptomatic patients, three with test positive EVD confirmation and one (who suffered Ebola contaminated needle stick contamination three days earlier) without lab confirmation all remitted symptoms within 2-4 days and fully recovered. All four ill cases had an immediate recovery course upon initiation of therapy. The single case of nonsymptomatic high-risk exposure treated preventively did not develop symptoms.

Conclusion. Ebola virus may have a very narrow window of redox infectivity capacity, which can be easily exploited with OT. OT may be a useful modality in EVD and other viral diseases and should be immediately studied to save lives that might otherwise be lost.

\section{References}

1. Rowen RJ, et. al. Rapid resolution of hemorrhagic fever (Ebola) in Sierra Leone with ozone therapy. Afr J Infect Dis.2016;10(1): 49-54. doi:10.4314/ajid.v10i1.10. 